\title{
Kriminalitetens eksistens - kategorisk form og stoff
}

\author{
Af Nicolay B. Johansen ${ }^{1}$
}

\begin{abstract}
In 2004 Nils Christie declared that "crime does not exist". In the resulting Norwegian debate, at least two diverging positions emerged. Leif Petter Olaussen claimed that crime is a "social reality", while Cecilie Høigård made the proposition that crime is "congealed power relations". In this article, I use the constructivist tradition to analyse the authors' various positions. Constructions are made of categories, and the ontological status of categories is a problem that runs through the last 1500 years of European thought, at least. I distinguish between three questions in relation to categories and constructivism: 1) Criminalization as a speech act: What does it mean to use this specific category? 2) What characterizes crime as a category? Here I distinguish between the form and substance of crime as a category; 3) How do the category and the social world interchange? Through these sub-questions I create common denominators for the aforementioned positions. I find that what first appears a metaphysical mystery may be understood in simple terms: the different authors disagree on the level of friction of legal norms "in action". Christie considers penal law as basically undetermined. On the other wing, Olaussen's claim is that crime is basically determined.
\end{abstract}

Nils Christie utløste en lengre debatt da han i 2004 erklærte at kriminalitet ikke finnes. Olaussen hevdet at kriminaliteten finnes likevel, og etter hvert var det flere stemmer som meldte seg på. Spørsmålet kan likevel fortsatt sies å henge litt i løse luften. I denne artikkelen vil jeg oppsummere debattene og prøve å rydde litt i de posisjonene som kom til syne. Dernest vil jeg sette posisjonene på samme formel, altså gjøre dem sammenlignbare. En slik sammenligning viser at det som startet som et metafysisk mysterium kan kokes ned til et spørsmål om hvor motstandsløst de strafferettslige bestemmelsene lar seg anvende i det daglige. Christie hevder handlingsbudene kun kommer til anvendelse etter lange forhandlinger,

* Title in English: The reality of crime - categorical form and substance. 
med høy grad av ubestemthet. Andre, som Olaussen, hevder at kriminalitetskategoriene mer friksjonsfritt legger seg ned over menneskers handlinger.

Opprydningen skal foretas med begrepet «konstruktivisme» som verktøy. ${ }^{2}$ Konstruktivismebegrepet gir anledning til å komme under overflaten på den ellers underlige tematikken, om noe kan sies å finnes. Det er likevel min påstand at de forskjellige syn vi finner på kriminalitetens eksistens ikke er avhengig av hvorvidt man har en konstruktivistisk tilnærming eller ikke. Det som kommer til syne er forskjellige typer sosiologi. Det som hevdes å være uenighet om hvorvidt kriminalitet kan sies å eksistere, koker ned et spørsmål om hvor tregt eller lett den sosiale kategorien kriminalitet kan knyttes til enkelthandlinger. Det blir et spørsmål om anvendelse av lovboken, en lovbok som i siste instans er et kulturprodukt som understøttes av folkelige begreper om rett og galt.

Jeg hevder at uttrykket «konstruktivisme» bør avmystifiseres. Konstruktivisme betyr ikke annet enn at samfunnslivet er organisert rundt kategorier. Disse kategoriene er fremkommet på forskjellige måter. Noen er vedtatt mens andre tilkommer oss gjennom tradisjonene. Men kategorier, som «kriminalitet», de finnes uansett om de kunne vært annerledes eller ikke. Alle er enige om at den juridiske og sosiale kategorien kriminalitet finnes, også de som debatterte kriminalitetens eksistens. Jeg fremfører den påstanden at kriminalitet som kategori sosiologisk sett både er kontingent og essensiell. Det er dette jeg viser til når jeg i tittelen omtaler «kriminalitetens» form og stoff. Mer interessant enn hvorvidt kriminaliteten finnes er det å skjelne mellom på den ene siden det at et begrep kriminalitet er en nødvendig bestanddel av et hvert samfunn, og på den annen side at måten denne kriminaliteten defineres varierer mellom forskjellige samfunn.

Spørsmålet blir heller hvordan denne kategorien brukes og hvilke sosiale betingelser som bestemmer om den kommer til anvendelse eller ikke. Og her er det mer relevant å peke på den tilgrunnliggende sosiologi. I denne artikkelen vil jeg vise til og skissere de sosiologiske posisjonene vi finner hos noen av debattens aktører.

\section{Den kontroversielle konstruktivismen}

Det er mange grunner til å unngå begrepet konstruktivisme. For det første er det upresist og dårlig forstått. Konstruktivisme omtales ofte som den tanke at fenomener er konstruert eller skapt. Det er i utgangspunktet en trivialitet (Hacking 2000), de færreste kulturprodukter vokser opp av skogbunnen. ${ }^{3}$ Ved å hevde at noe er skapt, har man i grunnen ikke sagt så veldig mye. For det andre er det lite egnet til å fange opp interessante forskjeller i samfunnsvitenskapelige posisjoner. Blant forfattere som skriver om sosiale fenomener som konstruert finner vi vidt 
forskjellige fremstillinger, alt i fra Searles analytiske filosofi (Searle 1995) til Foucaults mer eller mindre funksjonalistiske metafysikk. Man tar for seg alt fra konstruksjon av kunnskap (Eriksen og Kvilhaug 2002) til konstruksjon av sosiale fenomener (Berger og Luckmann 1992) og problemer (Spector og Kitsuse 1977). Og for det tredje er konstruktivismebegrepet ideologisk ladet. For noen er konstruktivisme praktisk talt en ideologi (Gergen 2001), og i de siste årene har konstruktivisme blitt skyteskive i den såkalte kulturkampen (Toje 2012), med folkene bak tv-serien «Hjernevask» og andre (Eia og Ihle 2010). Man risikerer således å virvle opp altfor mange konnotasjoner og bakenforliggende problemstillinger ved å se på Christies posisjon som en form for konstruktivisme, og det uten å oppnå noen særlig grad av presisjon.

Hacking har blitt en viktig referanse for mange konstruktivismekritikere. En ulempe med å henvise til hans bok, er at han, som en rekke andre filosofer, ikke går tilstrekkelig inn i problemstillingene i de sosiologiske idétradisjonene. Hans hovedanliggende er å problematisere vitenskapelig kunnskapsproduksjon. Den formen for konstruktivisme som kjennetegner deler av samfunnsvitenskapen, tar for seg hvordan sosialt produserte kategorier virker tilbake på samfunnslivet, hvordan bruk av kategorier skaper samfunnsliv. Det er forskjellige spørsmål. Fordelen med Hacking er at han setter konstruktivismen inn i en større kommunikativ sammenheng.

Det uuttalte premisset for konstruktivister, sier han, at vi har en tilstand som fremstår som uunngåelig. Budskapet kan forefinnes i tre former: 1. Det behøvde ikke vært sånn, 2. Det er problematisk hvordan det er, og 3. Det hadde vært bedre om det var annerledes (Hacking 2000).

Slik fremstår konstruktivisme mer som en relativiserende posisjon i en offentlig debatt enn noen egentlig sosiologisk eller vitenskapsteoretisk posisjon.

\section{Kategorier og tilbakeføring}

Christie skrev altså at Kriminalitet ikke «finnes» (2004), og fulgte opp med at «[h]andlinger er ikke, de blir». Handlinger har ikke mening i seg selv, de blir tillagt mening av omgivelsene. Kriminalitet er en slik mening. Men dette er form for mening som reduserer innholdet $i$ handlingen til en enkelt kategori som trumfer alle andre, moralsk fordømmelse og straffing. Å legge merkelappen kriminalitet på handlinger reduserer forståelsen og sperrer for alternative og mer fruktbare måter å respondere, sier Christie. «Det hadde vært bedre om det var annerledes».

Den etterfølgende debatten synliggjorde flere synspunkter, men det har i liten grad lyktes å formulere dem slik at de grunnleggende motsetningene er blitt mer tydelige. I fortsettelsen skal jeg se på spørsmålet om kriminalitetens ontologiske 
status, altså om den «finnes», på tre nivåer: Hvordan betraktes «Kriminalitet» som

1) talehandling,

2) som kategori, og til sist

3) hvordan vurderes koblingen mellom handling og kategori

På denne måten får vi tydeliggjort forskjeller i sosiologiske posisjoner.

I utgangspunktet er det to alternative posisjoner som er fremført. Leif Petter Olaussen hevder at kriminalitet må forstås som en «sosial realitet» og stiller seg eksplisitt i opposisjon (Olaussen 2004b; Olaussen 2004a; Olaussen 2007a; Olaussen 2007b). Selv om Christies og Olaussens formuleringer er uklare på mange punkter, utgjør de i hvert fall tilsynelatende ytterpunktene i debatten. Cecilie Høigård har hevdet det synspunkt at kriminalitet er et fenomen som viser til «størknede maktforhold» (Høigård 2003). Kriminalitet finnes altså, men viser til styrkeforholdet mellom forskjellige grupper. Kriminalitet er reelt men kontingent. Hun stiller seg i en viss forstand mellom de to andre, alternativt kan vi si hun lager en tredje posisjon. Men disse posisjonene kommer først ordentlig til syne når vi betrakter Christies påstand som kategori.

Jeg skal ta for meg Christies påstand (og svarene som er gitt) henholdsvis som talehandling, som kategori og som kategori i bruk. Sistnevnte er muligvis det mest avgjørende i sakens anledning, men for å forstå dynamikken i de sosiale prosesser vi har som emne, krever det at vi innledningsvis holder disse elementene fra hverandre.

Det at noe kalles en sosial konstruksjon viser til en tilbakeføringsprosess (Hacking kaller det en «vekselvirkning»). Man setter et ord på et fenomen, og så får bruken av dette ordet konsekvenser for praktisk liv. Spector og Kitsuse satte dette poenget på spissen i sitt banebrytende verk «Constructing Social Problems» i 1977. I sosiologien, sa de, var man i lang tid tilfreds med å tematisere en rekke fenomener som «sosiale problemer». Men dermed tok man for gitt de rådende forestillinger om hva som er problematisk. Forfatterne ville rette oppmerksomhet mot definisjonsprosessen som lå til grunn for at bestemte fenomener fikk merkelappen «sosiale problemer», og som dermed lå til grunn for å behandle disse som problematiske. Vi kan si at Spector og Kitsuse utfordret det konvensjonelle samfunnets håndtering av bestemte grupperinger innenfor egen befolkning, ved å påpeke at bruk av kategorier fører til «menneskelige konsekvenser» som kan være omtvistet. 
Disse ideene fantes allerede som kim flere steder i sosiologien bakover i tid, ikke minst $\mathrm{i}$ «thomasteoremet» (Thomas og Thomas 1928). Becker hadde senere formulert en kritikk av måten bruk av marihuana ble kriminalisert (Becker 1973/1963) og Cohen hadde formulert en egen teori om moralske panikker (Cohen 1980/1974), begge deler langs de samme linjer. For alle var definisjonen av handlingene det sentrale, og de tematiserte på forskjellige måter sosiale prosesser som lå til grunn for at forståelser av bestemte handlinger ble ansett som problematiske. Becker ble kjent for å legge vekt på stempling som en del av reaksjonene på ellers ikke ualminnelige avvik. ${ }^{4}$ Cohen viste til et samspill mellom pressen og «moralske entreprenører» som skapte et trykk i retning av utdefinering. Det grunnleggende fenomenet disse, og andre, forfattere tok for seg, var tilbakeføring til levd liv, gjennom bruk av bestemte kategorier.

Satt inn i skjemaet til Hacking, omtalt over, blir budskapet at det som kalles sosiale problemer kunne vært klassifisert annerledes. De fremstår som unngåelige fenomener, men kunne med litt annerledes håndtering vært enten unngått eller man kunne begrenset uheldige konsekvenser. Og det er i denne tradisjonen vi må forstå Christies utsagn. For å klargjøre dette poenget ytterligere kan vi se nærmere på hva som menes når uttrykket «kriminalitet» brukes.

\section{Hva sier man når man sier at noe er kriminelt?}

Med ordet «kriminalitet» menes vanligvis lovbrudd som rammes av straffebud. Vi har i dag en nokså fersk straffelov, selv om den ikke er satt i kraft (vedtatt i 2005). Stortinget har med andre ord vedtatt alle straffebudene. Forbudene mot incest (§ 312), drap (§ 275), skattesvik (§ 378) og stemmesalg (§ 152) er alle sammen drøftet og stemt over av folkevalgte personer (Straffeloven 2005/2008). De er kriminelle fordi stortinget har vedtatt at de er kriminelle.

Det er ikke nødvendigvis noe ved handlingene selv som tilsier at de skal straffes, det er noe som følger av et vedtak fattet i stortinget den og den datoen. Den gjeldende straffeloven er fra 1902, og det gir loven en viss tradisjonell tyngde. Men det undergraver på mange måter straffens tyngde at den er resultat av nyttebetraktninger, forhandlinger og avstemninger. ${ }^{5}$ Straffens symbolske vekt hviler på $i$ at den rettes mot handlinger som forkastes av fellesskapet $i$ en eller annen forstand. Rett nok er demokratiet det beste uttrykket for fellesskapets vilje, men tidligere snakket man om kriminalitet på en annen måte. Man snakket om handler som var onde i seg selv, «mala in se» på latin. Innenfor naturretten er lovens legitimitet gitt utenfra. Det er noe over menneskeheten som gir den legale orden. Handlingenes straffbarhet er gitt av Gud, og noe senere av naturens egen orden. Handlinger kunne ikke betraktes annerledes. Lovbrudd var iboende kriminelle. 
Naturretten har i forskjellige varianter preget lov og rett i all historisk tid fram til midten av det 19. århundre og er fortsatt viktig. Rettspositivismen vokste fram som et alternativ på slutten av 1800-tallet og ble den dominerende teori om retten i første halvdel av det 20. århundre. Rettspositivismen gir et sekulært grunnlag for rettsnormene. Litt forenklet kan vi at mens man i naturretten henviste til Gud og Natur for å gi retten legitimitet, viser positivistene til Grunnloven for å gi styrke til lovens bindende kraft. Etter andre verdenskrig vant naturretten atter innflytelse (spesielt gjennom menneskerettighetene).

Man tenker seg fortsatt handlinger som drap og incest som mala in se. Men med demokratiseringen har også vi fått en annen form for kriminalitet, handlinger som er «mala prohibita». Dette er slike handlinger som er straffbare fordi vi, folkevalgte organer, har bestemt at de skal være kriminelle. Verken Gudene eller Naturen krever at brudd på taushetsplikten (§ 209) og befatning med bestemte rusmidler (§ 231) er kriminalitet som sådan (Straffeloven 2005).

Kriminelle handlinger er som Christie påpeker, uønskete handlinger. Det er handlinger man prøver å forhindre. Når man bruker straffeloven som virkemiddel for å forhindre handlinger så låner man symbolsk og følelsesmessig vekt fra den tiden kriminalitet i seg selv viste til Guds orden. På samme måte kan man låne følelsesmessig energi når man snakker om noe man misliker helt spesielt sterkt. TV2 kunne for eksempel 11. november 2010 melde at prisene var «kriminelt høye». Saken handlet om at fanger i fengsel må betale høyere priser enn det som forlanges hvis man selv går i forretningene. Akkurat det er fangene forhindret fra å gjøre, og følgelig klager de over at de må betale mer for dagligvarer. Litt ironisk er det selvsagt at representantene for fangene selv snakker om handlinger som kriminelle på denne måten. Poenget er å illustrere hvordan man kan gi moralsk og følelsesmessig kraft i en anklage ved å bruke ordet «kriminalitet». Riktignok kan høye priser være resultat av ulovlig prissamarbeid som, gjennom spesiallovgivningen, har en strafferamme på 3 år (Konkurranseloven 2006: § 10, 30). De høye prisene kan således teknisk sett være forbundet med kriminalitet, men ikke mer enn på en hvilken som helst flyplass og andre turiststeder (for eksempel skisentre) hvor prisnivået er påfallende mye høyere enn andre steder.

Det å bruke ordet kriminalitet for å gi retorisk kraft forteller om begrepets symbolske verdi. Slik bruk er imidlertid ikke noe som er begrenset til fangers innsats for å få utnytte deres svært begrensete midler. Kriminalitetsbegrepet brukes på samme måte i politikken og i dagligtale. Man ser det også i bruk av andre begreper med tilsvarende assosiasjoner. I russisk politikk vil for eksempel de fleste omtale meningsmotstandere som «mafia». Og når avisene omtaler ungdommers brenning av biler i opptøyene i Frankrike høsten 2005, skriver de om «vol- 
den». Vold og mafia er andre begreper som forbinder beskrivelsen av handlingene med den moralske forkastelighet som ligger $i$ at noe er kriminelt.

«Det er helt kriminelt» kan man si, og på den måten understreker man at det som omtales ikke bare er litt forkastelig, men verdig fellesskapets samlede fordømmelse. Heller ikke kriminologer går fri fra denne måten å anvende kriminalitetsbegrepet. Kriminologi kan brukes til å fremme politiske interesser. Studier av økonomisk kriminalitet kan for eksempel være motivert av et ønske om at det skal satses mer ressurser på å avdekke slik virksomhet og ikke minst at det skal straffes hardere. I dag er den såkalte «grønne kriminologien» et bedre eksempel. Kriminologi som tar for seg miljøproblemer og dyrs rettigheter har en tendens til å fremstille tingenes elendige tilstand med den implisitte forventning om at noe som er så forferdelig burde vært straffet hardere (Johansen 2010).

Når man sier at noe er «kriminelt», så hevder man at den handlingen det refereres til er særlig klanderverdig. Man «gjør noe med ord» gjennom å henvise til en kulturell reserve av indignasjon. Alle er enige om det som er kriminelt er forkastelig, og når man trekker en handling(stype) inn under denne betegnelsen utløser man (forsøksvis) en rekke av reaksjoner mot gjerningspersonen.

Christies posisjon kan leses som et innspill i en bredere offentlighet, der han prøver å fravriste de mer straffevennlige (og hegemoniske) posisjonene deres definisjonsmakt. Hans virkemiddel er å vise til at det å kalle handlinger for kriminelle, er et valg, som kunne vært annerledes. Han viser til straffbarhet som kontingent egenskap. Og dette er villet retorikk fra Christies side, det samsvarer i alle fall med hans øvrige offentlige virke og forfatterskap for øvrig (Christie 1982b; Christie og Bruun 1996; Christie 1997a; Christie 2000). Man kan med rette si at Christie relativiserer kriminalitet som merkelapp på handlinger, jamfør Hackings inndeling over.

Men han redegjør ikke tilstrekkelig for de sosiologiske og vitenskapeteoretiske forutsetninger for sitt grep. Slik oppstår misforståelser. I et avisinnlegg blir for eksempel Christie kritisert for å hevde at kriminelle handlinger ikke er «virkelige» (Neumann 2011). At han undervurderer smerter og lidelser, er en misforståelse, men en misforståelse Christie lett kunne oppklart ved å uttrykke seg mer presist. $^{6}$

\section{Kriminalitet som kategori}

Hva er en kategori? Kategorier er betegnelser som samler flere enkeltfenomener (singulariteter). ${ }^{7}$ Singulariteter klassifiseres etter egenskaper. Roser, bakterier og mat er eksempler på kategorier. De samler planter med bestemte egenskaper, mikroorganismer med bestemte egenskaper og gjenstander mer generelt ut fra deres 
egenskap å tilby mennesker næring. Mat kan igjen deles i det som smaker godt og det som smaker vondt eller mellom det som er sundt og det som er usunt. Begrepenes- og kategorienes status har forvoldt problemer for filosofer fra historiens begynnelse. Aristoteles etablerte en logikk- og kategorilære. Da denne skulle oversettes til latin, på den tiden Romerriket gikk mot undergangen (ca år 500), bidro Boëthius med en liten kommentar. Her erklærte han at han lot spørsmålet om de allmenne begrepers ontologiske status stå åpent. Er de iboende i tingene, eller er de menneskelige påfunn? Dette spørsmålet skulle prege de neste 1100 årene fram til reformasjonen, så vel filosofien som kirkestrider, liv, død og kriger. «Universaliestriden» var også viktig for de klassiske sosiologene, om enn tematikken ikke er like gjenkjennelig i mer moderne filosofi. Men spørsmålet dukker opp igjen i forbindelse med debattene om konstruktivisme.

En kategori samler altså enkeltfenomener utfra deres egenskaper. Men hvilke egenskaper er viktige? Noen deler for eksempel dyrene inn etter hvor de lever. I Douglas' kjente eksempel er dyr som lever i høyden samlet under en fellesnevner, hvilket betyr at fugler og aper kommer under samme kategori (Douglas 1997). Dette eksemplet kan tjene til å illustrere at kategorier vi tar for gitt og iboende i tingene, kan være annerledes. I vår sammenheng er det viktigere hvordan vi klassifiserer handlinger og mennesker. I Norges offisielle statistikker skjelnes det for eksempel mellom besittelse av forskjellige mengder ulovlige rusmidler. Under terskelverdien klassifiseres handlingen som brudd på legemiddelloven. Over terskelverdien regnes det som brudd på straffeloven.

Kriminalitet er en samlebetegnelse. Den samler i første omgang underkategorier (tyveri, vold, besittelse av narkotika, telefonsjikane og veldig mange flere). Men i tillegg til å samle disse handlingstypene, gjør den noe med dem. Denne klassifikasjonen gir dem et moralsk stempel. Det er aldri en helt uskyldig øvelse å sette navn på noe, sier antropologene. Og dette gjelder i helt særlig sterk grad for å plassere en handling under kriminalitetsbegrepet.

Selv om han unngår å bruke ordet kriminalitet, finnes det situasjoner der også Christie mener det er rimelig å bruke straff (Christie 1982b; Hauge 1996). Følgelig anerkjenner Christie at det finnes en samfunnsmessig kategori som samler de handlinger vi fordømmer og straffer. Men Christie sier lite om straffeloven som kategori. Hans hovedanliggende er å problematisere hvordan man anvender denne kategorien.

Olaussen presenterer sitt syn i opposisjon til Christie, som en form for «realisme». Selv om han ikke kaller Christie konstruktivist, brukes ofte realisme og konstruktivisme som begrepsmotsetninger (Eriksen og Kvilhaug 2002). Når kriminalitet er en sosial realitet, sier Olaussen, er det fordi folk stort sett anerkjenner 
meningsinnholdet. Han kaller det en «enighetskategori». Med henvisning til blant annet Durkheim, Weber, Tranøy og Searle understreker Olaussen at kriminalitet er noe folk tar for gitt. Det er ikke uenighet som preger forholdet mellom loven og befolkningen, og spesielt ikke på strafferettens område. Selv tyven er oppmerksom på, og enig i at det er galt å stjele (Olaussen 2004b). Olaussen legger vekt på at kategorien kriminalitet er folkelig understøttet.

Det er likevel ikke helt opplagt akkurat hva det vil si at noe er en «enighetskategori». Kategorier er jo sjelden noe man blir enige om, de kommer kulturelt formidlet (som «kollektive representasjoner» hos Durkheim) eller blir pådyttet av personer med myndighet til slikt (for tiden er det aktuelt med hvordan arbeidslivet har blitt preget av New Public Management).

Høigård anerkjenner kriminalitet som sosial kategori, men hevder at det ligger interessemotsetninger til grunn for hvordan den er utformet. Hun viser til at det på 90-tallet fant sted en økning i anmeldelser for skadeverk, uten sidestykke i moderne norsk straffehistorie. Veksten i bruk av strafferett var rettet mot unge mennesker som selv kalte seg malere og som tegnet og skrev på vegger. Høigård viser til at det i offentligheten fant sted en dreining i forståelsen av graffiti i forkant av straffebruken. Pressen, politi og offentlige etater var aktive i redefineringen av graffiti. Med henvisning til Bourdieu hevder Høigård at ungdommene tapte definisjonen av hvordan deres handlinger skulle forstås. Dermed kunne det de gjorde behandles som kriminalitet (Høigård 2002; Høigård 2003).

Høigård fremfører et delt syn på kriminalitet som kategori. Rent eksplisitt fremmer hun det syn at det ligger interessemotsetninger under. Slik sett står det hun sier i motsetning til Olaussen som legger vekt på enighet. Men samtidig bruker hun begrepet definisjonsmakt og henviser til Bourdieu. Definisjonsmakten kjennetegnes av at den virker tilbake. Det er en subtil maktform som virker gjennom å være overbevisende også for dem som objektivt sett ikke har fordel av den aktuelle definisjonen.

Men hva er det ved kriminalitetsdefinisjoner som virker overbevisende? For det første forutsetter en slik definisjon at man aksepterer kriminaltetsbegrepets nødvendighet og gyldighet. Den spesifikke grensedragningen kan godt være kontingent i utslag av asymmetrisk makt, slik Høigård foreslår. Men hvordan skulle en definisjon virke naturlig eller overbevisende, dersom man ikke aksepterte kategorien kriminalitet i seg selv? I Bourdieus perspektiver på symbolsk vold og makt ligger det som Høigård påpeker tydelige konfliktteoretiske dimensjoner. Men samtidig forutsettes det en form for konsensus om de grunnleggende kategorier. Høigård er i andre sammenhenger mest opptatt av Bourdieus aktivistiske og 
Marxistiske sider, men det ligger også til grunn et Durkheimiansk begrep om kriminalitet som kategori.

Durkheim mente som kjent at kriminalitet var en nødvendig samfunnsmessig kategori, og hevdet $i$ en berømt passasje at til og med i et samfunn av engler, ville det eksistere kriminalitet (Durkheim 1982). Grensen for hva som regnes uakseptabelt og støtende følger relativt til universet av sosiale fenomener.

Dette er en viktig dimensjon å holde fast ved. Det Durkheim sier, er at alle samfunn vil ha en form for kategori, som definerer en moralsk utside, som setter en grense mot de handlinger gruppen finner så forkastelige at den vil rette en følelsesmessig reaksjon mot forøverne. Den første beveger i kriminalitet som kategori, er gruppens kollektive fordømmelse. Og alle grupper vil ha en slik grense. I følge Durkheim er altså ikke kriminalitet som kategori kontingent. Kan hende er det dette Olaussen sikter til med uttrykket enighetskategori? På den annen side vil begrepet variere med tid og sted, akkurat hva som erklæres uakseptabelt.

Her er vi ved et kjernepunkt i det aktuelle spørsmålet. Kategorien kriminalitet har den egenskapen at den både er kontingent og ikke-kontingent. Kan hende vil det hjelpe hvis vi låner det gamle begrepsskillet mellom form og stoff hos de gamle grekerne.

\section{Form og stoff ${ }^{8}$}

Spørsmålet om enkelttingenes forhold til kategoriene er helt gjennomgående hos Aristoteles. Når man tar for seg en rekke likeartede gjenstander danner det seg et bilde av en «egentlig» egenskap ved dem. For Platon kjenner vi temaet som «ideer». I Hulelignelsen kan man snu seg og se figurene som danner skyggebilder på veggen foran, og disse figurene utgjør et slags abstrahert ideal. Når man abstraherer fra de konkrete gjenstandene får man tingenes «form», det som er allment ved dem. Tingene kan hver for seg avvike fra formen i større eller mindre grad. Formen angir tingenes vesen, mens de stofflige sider gir tingenes foranderlige egenskaper.

Å snakke om kriminalitetens form og stoff er på en måte å gjøre vold mot begrepene. Begrepsparet form og stoff er myntet på enkeltgjenstander, og ikke kategorier. Men kategorier er i en viss forstand også ting. Poenget er uansett at kriminalitet som kategori har en dobbelthet på samme måte som ting. Det er noe ved tingene som har almen karakter, og så er det noe ved dem som er foranderlig og tilfeldig. I vår sammenheng kan vi snakke om kriminalitetskategorien, hvis form er bestemt mens dens stoff er kontingent.

For igjen å påkalle Durkheim, kan vi si at alle samfunn vil reagere med en form for ostrakisme overfor drap. Men hva er drap? Hvis det er å avslutte livet til 
et annet menneske, kan spørsmålet synes enkelt. Men gjelder det alle mennesker? Gjelder det også mennesker som ligner lite på gruppen ellers? Historien er full av uklare definisjoner på hvem som tilhører menneskeslekten. Og hva med ufødte liv? Her finner vi forskjellige synspunkter rundt omkring på kloden, og bakover i tid. Christie nevner barmhjertighetsdrap. Spørsmålet om aktiv dødshjelp har ikke stormet i Norge på samme måte som i Nederland, men det er likevel aktuelt som eksempel på at måten at måten vi definerer drap ikke er skrevet i stein på samme måte som at man ikke skal drepe.

Her ligger også kriminalitetsbegrepets retoriske kraft: hver gang vi kaller noe for kriminalitet, påkaller vi begrepets form. Formen, at det finnes en moralsk utside, som vekker forargelse, er iboende i alle gruppedannelser og samfunnsformasjoner. Men når kriminalitetsbegrepet utvides, av Stortinget, forandres kategoriens stofflige side. Denne er kontingent, og uten direkte forbindelse med kollektive følelser. Men disse følelsene kan aktivt vekkes til live, med henvisning til handlingens status som «kriminalitet».

Noen handlinger er opplagt å klassifisere under mala in se, og hører mer udiskutabelt inn under det vi kaller straffeloven. Vold strengt definert og drap er vanskelig å tenke seg regulert gjennom sivilretten. Men når straffelovens egenskaper i stigende grad har blitt påført handlinger som ligger utenfor alminnelige oppfatninger av mala in se, kan man betrakte dette som utnyttelse av en følelsesmessig reserve $\mathrm{i}$ folks rettsoppfatning.

På denne måten blir det å kriminalisere like mye en handling, som det å undergrave kriminalitetsbegrepet. Det er et sterkt virkemiddel med tung symbolkraft. Og i denne sammenhengen er det ikke urimelig å påpeke hvordan noen typer lovbrudd klassifiseres under straffeloven og kriminalitetsbegrepet, mens andre skjermes for de samme konnotasjonene. Hvorfor er tyveri noe annet en skatteunndragelse? Det må være relevant å påpeke at straffeloven og fengslene først og fremst treffer allerede fattige og marginaliserte mennesker (Christie 1982a; Skarðhamar 2002; Friestad og Hansen 2004; Mathiesen 2011).

En versjon av den samfunnsvitenskapelige konstruktivismen legger vekt på kampen om definisjonene. Hvordan skal en allerede etablert handlingskategori plasseres i det moralske landskapet? I Cohens omtalte studie var spørsmålet aktualisert av ungdommer som erobret offentlige rom og til dels oppførte seg bøllete på kjente feriesteder. Becker problematiserte bruk av marihuana. Skal disse personene og handlingene plasseres inn under straffelovens institusjonelle rammeverk eller ikke? Retten til å definere har tradisjonelt ligget uutfordret hos den suverene hersker og politisk øvrighet. 
Vi må likevel slå fast at ingen av de omtalte parter benekter eksistensen eller berettigelsen av kategorien kriminalitet. Men vi aner betydelige forskjeller i hvordan denne kategorien oppfattes. Disse forskjellene blir klarere når vi ser nærmere på hvordan kriminaltetskategorien kommer til anvendelse.

\section{Koblingen mellom kategori og handling}

Straffeloven angir en rekke bestemmelser for hva som er forbudt og straffbart. Men hvordan kobles lovbestemmelsene til handlingene? I det følgende skal det hevdes at Christie fremstiller disse koblingene som grunnleggende sett ubestemt. Motsatt opererer Olaussen med en grunnleggende sett bestemt kobling. Begge disse måtene å tenke sammenhengen mellom liv og lov er utilstrekkelige. Hvis vi ser på sosiologien som ligger til grunn for deres fremstillinger kommer begge perspektiver til kort. For å anskueliggjøre dette poenget vil jeg med utgangspunkt i Christies eget eksempel vise hva slags sosiale forhold som påvirker kobling mellom kriminalitet som kategori, og enkelthandlinger.

Utgangspunktet her er bestemmelser om handlinger som angir om de tilhører en kategori som kriminelle. ${ }^{9}$ I det følgende skal vi fokusere på et annet ytterligere kompliserende element: det skjønnet man ikke kommer utenom når lov skal koples på liv. Det er uhyre sjelden at lovens kategorier fester seg til handlingen og personen som begår den helt av seg selv. Det er for eksempel vanskelig å tenke seg et lovbrudd uten at en person (kunne) anmeldt forholdet. Å anmelde forutsetter at et menneske klassifiserer en enkelthandling som en type handling innenfor det som er kriminalisert. Anmeldelsen er inngangen til det som kalles straffesakskjeden.

Christie gir flere eksempler som viser at bruken av merkelappen kriminalitet er et resultat av måten samfunnet er organisert mer enn egenskaper ved handlingene selv. En mann kveler sin hustru. For politiet er det et drap. Men når vi blir kjent med historien ser vi at det også kan tolkes som en kjærlighetshandling. Den kjente tyske sosiologen Dahrendorf forteller at han «tok» bøker i bokhandlene i de kaotiske dagene etter kapitulasjonen i 1945. I disse dagene hadde man i Tyskland ingen statlig autoritet. Kan det da kalles tyveri? En liten jente tar penger fra mors pengepung. Er det rimelig å kalle dette tyveri, spør Christie? Nei, fordi vi som oppdager det vet for mye om barnet. Og når gale mennesker på institusjon slår, sparker og biter personalet, tenker vi på det som noe annet enn vold. Christie er opptatt av at samfunnsorganisasjonen skaper rammer for hvordan vi tolker ubehagelige hendelser. Christie kaller det «uønskede handlinger» og «trøbbel». Uønskede handlinger kan settes inn i en strafferettslig ramme, men det krever at 
vi ikke ser det andre mennesket som et helt menneske med sammensatte egenskaper.

I et eksempel fra en park blir dette poenget gjort spesielt tydelig. Han ber oss se for oss en park omgitt av boligblokker. Det er sommer, sol og søndag morgen. Mennesker sitter på verandaene sine og spiser frokost eller leser avisen. Eksempelet gjengis i sin helhet (Christie 2004: 15-16).

En tykkfallen man kommer til syne i parken. Han har med seg noen plastposer og slår seg ned på gresset med posene. Det klirrer i dem, ølflasker kommer til syne, og han åpner en, to og flere. Han snakker litt med seg selv, og også til noen barn som samles rundt ham. Han snakker og synger - til glede for sin unge tilhører.

Etter en tid reiser han seg, går mot noen busker i nærheten, og åpner buksesmekken. Flere av barna følger ivrig etter.

Her må vi tilbake til de to nye boligblokkene med søndagsfolket på verandaene. De ser helt like ut, disse blokkene, men forhistorien deres er langtfra lik. Den ene blokken ble bygget på moderne vis og helt etter oppskriften. Alt var ferdig da beboerne flyttet inn. Nøkkel i dør og en effektiv heis fra garasje i kjelleren og opp til egen etasje. Det perfekte bygg.

Den andre blokken hadde en mer turbulent forhistorie. Entreprenørfirmaet gikk konkurs. Kjøperne hadde betalt på forskudd, men det hjalp lite, her var ikke penger å hente, bare et nesten ferdig hus. Heisen fungerte ikke, ytterdører var ikke satt opp, kjøkkener var uferdige og fortauet en giørmesti. En desperat situasjon. Beboerne ble tvunget i gang med dugnad fra første dag. Dører, kjøkken, gjørmehav - det tok måneder med hardt arbeid og påtvunget dugnad for å skape levelige forhold. Det miserable bygg ville vært et passende navn på denne blokken.

Så tilbake til mannen i parken.

Halvt skjult i buskene, omgitt av småbarn, og med vidåpen buksesmekk - det er en situasjon som også er vidåpen for tolkningsmuligheter. I det miserable bygg var saken klar. Mannen i buskene er Per, sønn av Anna. Han falt ned fra stellebordet som liten, er litt rar, men snill som midtsommerdagene er lange. Han er glad i øl. Om han drikker for mye, må man ringe hjem til ham så kommer noen og henter.

I det annet hus, det perfekte bygg, der er situasjonen en helt annen. Ingen kjenner ham. En underlig mann omgitt av barn. Han er i ferd med å vise fram penis. Noen av tilskuerne fra balkongene griper mobiltelefonene og tilkaller politiet. Et tilfelle av blotting er observert, kanskje er det mulig å forhindre en enda alvorligere seksualforbrytelse. (...)

I det perfekte hus visste de ikke noe om Per og Anna, og ville heller ikke få vite noe på årevis. Om de ikke personlig ville gripe inn, hadde derfor som samvittighetsfulle borgere bare den mulighet tilbake å tilkalle politiet. Som følge av den manglende konkurs i det perfekte bygg, ble Per sett som en potensiell kriminell, mens han konkursbyggets hjelp ville bli hjulpet hjem til sin mor. Begrensede kunnskaper innenfor et sosialt system åpner i tilfeller som disse for at handlinger utenom det vanlige sees som kriminelle.

Utdraget illustrerer Christies sosiologiske blikk på tilværelsen gjennom hans ironiske (?) blikk på det gode samfunn. Han ser sosial integrasjon der andre ser 
ulykker og elendighet. En konkurs blir til et inkluderende fellesskap, mens det vellykkete bygg fører med seg isolasjon og utestengelse. Blokken der mennesker var tvunget til å kjenne hverandre så hverandre som personer med sammensatte egenskaper, og hadde dessuten blitt kjent med andre i lokalmiljøet (blant annet Per og Anna). I det perfekte bygget kunne man ta nøkkelen som sto i døra og gå inn, uten å bli kjent med verken naboer eller nabolag. Dermed fremsto mennesker man observerte i større grad gjennom de handlingene de til en hver tid foretok seg. Som fremmede ble små tegn som kunne tolkes som truende tolket som nettopp trusler. Utdraget fortsetter som følger (Christie 2004: 16):

Folk uten fellesskap i samværssituasjoner vil vite lite om hverandre. Informasjon går tregere. Ved kriser vil man i større grad bli avhengige av offentlige funksjonærer. Men enkelte typer funksjonærer produserer kriminalitet gjennom sine inngrep. Politiet er i analog situasjon til Kong Midas. Alt han berørte ble til gull, og som vi vet fra legenden, døde kongen av sult. Mye av hva politi og fengselsvesen berører, blir til kriminalitet og kriminelle, og alternative tolkninger av handlinger og aktører blir svekket eller borte. På ny: Handlinger er ikke, de blir. Folk er ikke, de blir.

«På ny» sier Christie i siste linje. Det er fordi han har sagt disse tingene tidligere. ${ }^{10}$ I 1993 fremmet han de samme synspunkter i en annen bok, etter å ha gjengitt et eksempel med en gutt som tar penger hjemme, har slått broren og ikke snakker sant om forløpet i etterkant. Eksempelet er parallelt med den lille jenta nevnt over. Men her kjenner vi gutten som grunnleggende sett ærlig, og for det meste trøstende. Og gutten er først og fremst sjenerøs overfor vennene sine. «Men slik er det ikke nødvendigvis med den fremmede gutten som nettopp er flyttet inn i nabohuset» (Christie 2000: 21-22). Videre heter det:

Handlinger er ikke. De blir. Slik er det også med kriminalitet. Kriminalitet eksisterer ikke. Kriminalitet blir skapt. Først er det handlinger. Så følger en lang prosess med å gi mening til disse handlingene. Her er sosial avstand og maktforskjeller svært viktige faktorer. Avstand øker tendensen til å gi handlinger den mening at de er lovbrudd og personer den betydning at de er kriminelle. ${ }^{11}$

Her er vi ved kjernepunktet hos Christie. Når han sier kriminalitet ikke finnes, er det en påstand som viser til det ubestemte i en hver situasjon. Det foregår forhandlinger om hvordan situasjonen skal defineres. 


\section{Forskjeller i sosiologi}

Motsatt hevder Olaussen at kriminalitet $i k k e$ er resultat av forhandlinger. Forståelsen av handlingens betydning er (som oftest) åpenbar for de fleste involverte parter, man er som han sier, «enige». Det er en «enighetskategori». Kriminalitet er ikke navn på et konfliktområde. Grensene for det fellesskapet aksepterer er nedfelt $\mathrm{i}$ en form for kollektiv bevissthet (med henvisning til Durkheim) eller en «allmenmoral» (Tranøy) (Olaussen 2004b).

Olaussens kritikk av Christie er formulert i programmatiske vendinger. Selv om han nevner eksempler der forhandlingsperspektivet er mindre passende, tilbyr han ikke et moteksempel av tilsvarende argumentativ verdi, som tilfellet med Arne i parken. Men på denne måten lar Olaussen det stå åpent hvordan tilbakeføringsprosessene faktisk foregår.

Høigård presenterer på sin side et eksempel med tydelige svar på spørsmålet om tilbakeføring. Hennes studie av taggere/malere på nittitallet, hevder hun at det sosiale fenomenet hun tok for seg, ble definert som problematisk i et samspill mellom pressen (Aftenpostens dekning) og moralske entreprenører som Oslo Sporveier og Byrådet i Oslo. Videre viser hun at så vel politiet som vektere og ansatte i Sporveiene var uvanlig driftige i å forfølge denne typen saker. Det var ikke forhandlinger som preget møtene mellom ungdommer og kontrollører. Maktforskjellene viste seg i at kontrollørene hadde nokså fritt spillerom å både definere saker som politianliggender, og sluse dem inn i straffesakskjeden. De tiltok seg også rett til å gå utover sine beføyelser, og dele ut det Høigård kalte «gatestraffer». Med gatestraffer mener hun plaging av ungdommer tatt med sprayboks, som ikke kunne straffes på grunn av ung alder. De ble likevel tatt med på politistasjonen og holdt innesperret et kortere tidsrom, og/eller fratatt dyre tusjer, spraybokser og annet utstyr (Høigård 2002; Høigård 2003). ${ }^{12}$

Diskusjoner om kriminalitet står seg alltid på å være konkrete. Christie har utvilsomt rett når han påpeker at kriminalitet er et ord som dekker såpass mange forskjelligartede fenomener, at det fort blir meningsløst å snakke om dem samlet. Det ville også krevd mer enn anledningen tilbyr å diskutere sosiale prosesser som ligger til grunn for vekselvirkninger mellom handlinger og kriminalitetskategorier. Det ville krevd en bredere diskusjon omkring medias posisjon og endringer. Man kunne diskutert betydningen av urbanisering, arbeidsdeling, utdanning, klassespørsmål og likhet mer utfyllende. Sosiale forhold i alle avskygninger vil nødvendigvis spille inn på bruken av kriminalitet som kategori. Jeg vil kort nevne politiet som eksempel.

Det er med andre ord mange forhold som spiller inn på om en sak havner i straffesakskjeden eller ikke. Gjennom å se på hvilke faktorer som påvirker politi- 
organisasjonens gatebyråkrater og deres bruk av skjønn kan man fremheve to dimensjoner:

1. Organisasjonskulturen er i endring (Granér 2004; Halvorsen 2005; Egge, Berg et al. 2010). Et «legalistisk» perspektiv har vunnet fotfeste og utgjør et konkurrerende paradigme overfor det det mer tradisjonelle machopregete perspektiv (Granér 2004). Som helhet er politiorganisasjonen dreid i legalistisk retning, noe som ikke minst er synlig i reduksjonen av det man kalte politivold. Samtidig består mange av de kjente mønstre i møter med tradisjonelle filleproletarer og deres sosiologiske etterkommere. Grensene for hvem som inkluderes i det moralske fellesskapet og de som «inkluderes» i straffesakskjeden er også i forandring. Organisasjonskulturen er igjen påvirket av samfunnsmessige endringer i forståelsen av forskjellige former for avvik, innføring av 3-årig høyskoleutdanning, sammensetningen av tjenestepersoner og endrede idealer for politiarbeid (Egge, Ganapathy et al. 2008; Fekjær 2014).

2. Politiets organisasjon har gjennomgått endringer som preger møtene mellom etaten og befolkningen på forskjellige måter: Nærpolitiet ble etablert som ideal på begynnelsen av 80-tallet (Ekanger 1981; Politirolleutvalget 2005). Slik ble det lagt til rette for at den sosiale avstanden mellom tjenestepersoner og publikum skulle reduseres og følgelig at bruken av straffesakskjeden skulle begrenses. De siste årene har også tillit blitt et mål for politiet som etat (Runhovde 2010). På den annen side har politi-Norge reelt sett blitt sentralisert i de 30 påfølgende årene, noe som på sin side har økt den sosiale avstanden (Politirolleutvalget 2005; Larsson 2010). Innføring av New Public Management har muligvis skapt større avstand mellom ledelse og det operative politiarbeidet. Og med den såkalte nulltoleransepolitikken (Lundgaard 2011) har skjønnsrommet for den enkelte tjenesteperson blitt redusert og styrt i retning av å bruke straffesakskjeden mer aktivt.

Utviklingen i politiet angir ikke noen bestemt retning på hvordan bruken av kriminalitet som kategori endrer seg. Og det er kan hende det beste med dette eksempelet. Sosiale prosesser er såpass sammensatte, og rommer så mange dimensjoner, at den viktigste lærdommen blir, at samfunnsliv krever detaljerte studier for å tillate enkle konklusjoner. I tillegg forteller dette raske blikket på politietaten at det er et mangfold av sosiale størrelser som virker sammen former bruken av kriminalitet som kategori og anvendelsen av denne kategorien.

Det er ikke vanskelig å gi Christie rett i at sosial avstand er viktig. Eksemplene hans taler for seg. Men temaet her er større, bruk av kriminalitet som kategori helt generelt. Høigård er nødvendigvis inne på noe viktig når hun påpeker det asymmetriske maktforholdet mellom ungdommer og politi og myndigheter. 
Maktforskjellene spiller både inn i opinionsdannelse og prioriteringer i kontrollorganisasjoner.

Olaussen sier derimot ikke så mye hva som ligger til grunn for anvendelse av kriminalitet som kategori. Hans poeng er jo at dette er en «enighetskategori», og da er det ikke nødvendig å vise til sosiale bakenforliggenheter. Olaussen innbiller seg likevel ikke at kriminalitet som kategori forholder seg sømløst til universet av handlinger. Ironisk nok er det ingen i Norge som har vært flinkere enn akkurat Olaussen til å fremvise det kontingente ved anmeldelsestallene i kriminalstatistikken (Olaussen 1981; Olaussen 1992; Olaussen 1995; Olaussen 1996a; Olaussen 1996b). Det er derfor naturlig å anta at Olaussen også er oppmerksom på at handlinger i en viss grad er ubestemt i sitt forhold til kriminalitetsbegrepet. Men Olaussen vektlegger enigheten om definisjoner mer enn Christie, og det er derfor han ikke løfter dette fram i sakens anledning.

I de omtalte arbeidene stiller han aldri spørsmålet om det er sosiale variabler som spiller inn. Når han diskuterer endringer i politiets måte å håndtere det vi i dag kaller familievold, viser han hvordan politiet har endret rutiner. Eksemplene hans er tydelige, forhold de tidligere ble tilkalt for som «husbråk» var svært alvorlige. Man valgte likevel ikke å gjøre dette til straffesaker (Olaussen 1995). Etter hvert endret man praksis og i dag er det offentlig påtale i slike saker (det vil si at politiet sender tilfellet inn i straffesakskjeden uavhengig av offerets anmeldelse). Men Olaussen bruker ikke slike funn som anledning til å plassere seg $\mathrm{i}$ et sosiologisk landskap, slik vi har sett hos Christie og Høigård. Det er antagelig to grunner til dette. For det første har han ikke data som belyser spørsmål om hvorfor for eksempel politiet endrer praksis overfor vold mot kvinner. Olaussen har alltid vært en streng empiriker. Og for det andre, i sammenheng med det forrige momentet, står han for en mer begrenset sosiologi.

Olaussen henviser som nevnt til et mangfold av forfattere. Disse forfatterne kan leses på forskjellige måter og ytterligere må det kunne hevdes at det er potensielt store spenninger dem imellom. Det kan likevel se ut som Olaussens tenkemåte er mest beslektet med Searles perspektiver (se også Skog 2006). Det betyr at Olaussen opererer med en form for metodologisk individualisme og gir «kausal forrang» til forklaringer som vektlegger menneskelig intervensjon. Stilt sammen med Christies eksempel, vil Olaussen være opptatt av at det er enkeltpersoner som går inn i situasjonen. Både naboer og politi vil betraktes som rasjonelle aktører situasjonen som oppstår. Typisk vil man innenfor analytisk sosiologi legge mindre vekt på hvordan situasjonen fremstår som forskjellig for de impliserte parter. Olaussens poeng er da også at partene er «enige». Det viktige er at man har en felles forståelse: man er enige om at blotting er galt og møtes med en felles 
forståelse av den aktuelle situasjonen. Man ser det samme og har de samme referansene. Slik blir også koblingen mellom kategorien kriminalitet og handling mindre ubestemt, - altså mer bestemt.

Olaussen er mindre opptatt av sosial avstand. For ham er det av større betydning at de involverte kommer fra samme gruppe i en viss forstand. Han vil heller ikke legge avgjørende vekt på politikultur og institusjonelle innretninger som former tjenestepersonenes skjønn.

Sosial avstand er som tidligere nevnt avgjørende i Christies sosiologi. Samtidig fremhever han situasjoners kontingens, de kan utspille seg forskjellig. Han omtaler dette som at det finner sted langvarige forhandlinger om definisjonen av situasjonen. ${ }^{13}$ Slik blir koblingen mellom lovens bestemmelser og de enkelte handlingen grunnleggende sett ubestemt.

Når Christie, Høigård og Olaussen diskuterer om kriminalitet finnes eller ikke, handler dette således om forskjellige sosiologier. I Christies sosial-avstandsosiologi fremstår bruken av kriminalitet som kategori som betinget av mellommenneskelig distanse i den sosiale struktur. Hos Høigård blir kriminalisering et virkemiddel som uttrykker maktforskjeller. Olaussen mener de to øvrige overdriver kriminaliseringsinstituttets kontingens.

\section{Grad av bestemthet}

Olaussen fremhever handlingers bestemthet. Det er ikke vanskelig å finne eksempler på situasjoner der de aller fleste ville vært enige om handlingens status. Olaussen hevder det er enighet om hvilke handlinger som passer i forskjellige legale definisjoner. Han legger vekt på institusjonaliserte forståelser av handlinger, at det i befolkningen ikke bare er en slags enighet om hvilke handlingstyper som skal straffes, men at det også er en slags enighet omkring hvilke handlinger som faller inn under dem. Olaussen kritiserer Christies bruk av eksempler, og antyder at de kan virke forførende i forhold til hans poeng. Hvordan hadde Christies påstand stått seg om man for eksempel tok utgangspunkt i et tradisjonelt sykkeltyveri? Det er kun i helt tenkte og lite relevante sammenhenger at det å bryte opp en lås for deretter å fjerne en sykkel vil oppleves som en vanskelig definerbar situasjon.

På den annen side er det åpenbart slik at sosial avstand på et samfunnsmessig plan innvirker på hvordan befolkningen opplever krenkelser. Christies posisjon kan oppsummeres som at han vektlegger handlingers fundamentale ubestemthet. Christie legger an et forhandlingsperspektiv på subsumering av hendelser under lovkategorier. Han sier til og med at en handling utløser en langdryg definisjonsprosess. Det som bestemmer om noe plasseres i en kriminalitetskategori, 
hevder Christie, er i den store sammenhengen den sosiale avstand. Med økt sosial avstand regnes flere handlinger som kriminelle. Med redusert sosial avstand oppfattes handlinger som del av mer helhetlig vurdering av personen og omgivelsene. Og dette poenget kunne faktisk vært forsterket, om han hadde tatt for seg de forhold ved politiet som spiller inn på hvorvidt en observert eller rapportert handling får et strafferettslig forløp. Det utspiller seg på mange flere arenaer enn det som diskutert over. Skjønnet spiller inn også politiets mottak for anmeldelser, både ved personlig fremmøte (Lie 1999) og ved telefonkontakt (Rønneberg 2008). Og selv om politiets eget skjønn ikke er avgjørende etter den nye muligheten for å anmelde noen former for kriminalitet på nettet, gir dette også helt nye rammer for hva som etter hvert blir regnet som kriminalitet.

Grunnen til at Christie ikke fremhever disse momentene er etter alt å dømme at begrepene omkring sosial avstand er så grunnleggende $\mathrm{i}$ hans sosiologi, at alle andre dimensjoner kommer i bakgrunnen. Fokuset på sosial avstand fortrenger oppmerksomheten fra andre sosiologiske variabler, som for eksempel institusjoner (Johansen 2008; Johansen 2010b).

\section{Symbolsk kraft}

Hvordan skal vi oppsummere disse posisjonene i lys av de konstruktivistiske tradisjonene? Det Christie og Høigård har felles, er at de skriver om sosiale fenomener gjennom å vise hvordan måten vi klassifiserer fenomener er med på å skape disse fenomenene. Den sosiale virkeligheten er kontingent, noe som vises på to måter: Vi kunne hatt andre kategorier og vi kunne brukt kategoriene annerledes (subsumert på en annen måte).

Hacking setter som nevnt konstruktivisme inn i en helhetlig kommunikativ sammenheng (Hacking 2000). Det som kalles konstruksjonisme er tekster som stiller spørsmål ved (natur-) nødvendigheten av en bestemt ordning. Premisset er som oftest at man har en ordning som oppfattes som uunngåelig. Når man sier at en ordning er konstruert, sier man som et minimum at denne ordningen ikke er uunngåelig og utfordrer den rådende oppfatning.

Er «kriminalitet» en uunngåelig kategori? Tidligere ble det hevdet at det å hevde at en handling, eller en type handling, er kriminell, er å «gjøre noe med ord» (for å bruke Searles (1969) berømte formulering). Det man gjør er tilsynelatende en uskyldig handling, i den forstand at man plasserer en handling inn under en kategori. Men slik plassering har alltid konsekvenser, og i vårt tilfelle spesielle konsekvenser, ved at samfunnets voldsmonopol blir aktivisert. Gruppens følelsesmessige reaksjoner blir satt i sving. Fordi kriminaliseringsinstituttet er en nødvendig bestanddel i ethvert samfunn, kan man med henvisning til dette, skape 
folkelig røre. ${ }^{14}$ De naturrettslige dimensjoner (mala in se) virker over på de mer tilfeldige sider (mala prohibita). Det at kriminalitet både har en stofflig og formlig del, innebærer at begrepet har både symbolsk kraft (vekker følelser) og kan tilpasses mer vilkårlig. Poenget her er at kriminalisering, bruk av kriminalitet som kategori, i prinsippet kan overdrives og misbrukes. Christie og Høigård utfordrer grunnlaget for denne virksomheten.

Hacking hevder videre at konstruktivistiske tekster kan finnes i flere varianter. Den historiske konstruksjonist påpeker at ting ikke alltid har vært slik de er nå. Ironikeren kommenterer på ordningers manglende legitimitet $\mathrm{i}$ en naturlig orden. Mer vanlig er det at man vil noe med å påpeke ordningers konstruerte status. Hacking skiller mellom de som vil «demaskere» den naturlige orden og de som vil reformere den. Reformatorene finnes i grader, opprørerne og de revolusjonære.

Selv om det finnes spor av ironi i Christies arbeider, har han en tydelig dagsorden. Han vil bidra til at vi bygger bedre samfunn, et tettere samfunn (Christie 1982a) der impulsen til å straffe er svakere (Christie 1982b; Christie 2000; Christie 2004). Det er likevel ikke helt treffende å kalle hans virksomhet for opprør eller revolusjon. Han vil demaskere og reformere. Høigård kan nok leses som en mer konfronterende forfatter, men innenfor hennes faglige virke er også hun en reformerende forfatter. Det finnes en opprørsk, om ikke revolusjonær posisjon i kriminologiens idéhistorie, omtalt som abolishonisme (Hauge 1996). Abolishonistene ville oppheve bruken av fengsler. Men verken Christie eller Høigård kan med rimelighet regnes med her.

Hvis man vil kritisere Christies posisjon er det lite treffsikkert å kalle ham for konstruktivist. De fleste samfunnsvitere opererer med elementer av konstruktivisme, hva skulle de ellers gjort? Kritikken må formuleres mer presist. Mener man at Christies fremstilling i for stor grad gjør kategorien kriminalitet historisk betinget (dens stofflige karakter)? Eller mener man at han i for stor grad gjør bruk av kriminalitetskategorien til et resultat av forhandlinger? Tilsvarende kan man spørre om Høigårds fremstilling i overvurderer befolkningens formbarhet når det gjelder oppfatning av tusjtegninger og graffiti på vegger. Og finnes det ikke motkrefter som veier opp maktforskjellene mellom ungdommer og myndigheter?

Men spørsmålets kjerne handler nok først og fremst om i hvilken grad kriminalisering som sosialt virkemiddel skal få ha sin symbolske kraft i fred. Og for å utfordre dette, har samfunnsvitenskapen et svært effektivt retorisk virkemiddel. Det å kalle noe kriminalitet er en talehandling der man tar i bruk tung symbolikk. Det er svært enkelt å forbinde en handling med moralsk fordømmelse ved å anvende dette ordet. Kanskje for enkelt. Det er gode grunner til å stille spørsmåls- 
tegn ved slike øvelser, spesielt for en disiplin med pretensjoner om å uttrykke seg vitenskapelig om sitt objekt.

\section{Noter}

1. Nicolay B. Johansen er post.doc. ved Institutt for kriminologi og rettssosiologi, Universitet i Oslo. Johansen arbeider på et prosjekt om kontroll med irregulære migranter og rusmisbrukere, «Insiders outside/outsiders inside». Dette prosjektet inngår i et større prosjekt «Kriminalittskontroll ved Europas grenser», ledet av professor Katja Franko Aas i Oslo. Johansen har tidligere skrevet om sosial kontroll, både med teoretiske perspektiver og rettet mot andre former for praksis.

2. Ordene konstruktivisme og konstruksjonisme brukes til dels om hverandre. Jeg anvender konstruktivisme av den grunn at det er mest utbredt i den litteraturen jeg forholder meg til. I følge Hacking, se nedenfor, burde jeg sannsynligvis valgt annerledes.

3. Takk til Thomas Ugelvik for formuleringen.

4. Foucaults posisjon kan forstås som en mer radikal versjon av Beckers poeng. Foucault hevder at fengslene som en del av et samfunnsmessig klassifikasjonsapparat skaper det klassen den erklært skal bekjempe (Foucault 1999).

5. På samme måte som det undergraver bibelens status som Guds ord hvis man påpeker at den er vedtatt på forskjellige kirkemøter.

6. Verken Høigård eller Olaussen kommenterer denne dimensjonen ved Christies posisjon.

7. Det følgende avsnittet er basert på kapittel $\log 2$ i min PhD avhandling (Johansen 2008).

8. Dette er grunnleggende temaer for filosofien, kjent for de fleste gjennom forskjellige former for forberedende prøver ved universiteter.

9. Fra juridisk hold vil dette fremstå som enkelt, enten er handlingen forbudt eller så er den tillatt. I møtet med virkeligheten er sammenhengen mer sammensatt og til dels uavklart, det finnes en rekke tilfeller der rettskildene ikke gir entydig svar. Når man snakker om det reelle kriminalitetsnivået, altså både registrert kriminalitet og mørketall, ligger det et premiss om at dette nivået prinsipielt sett er avgrensbart. Det medfører sannsynligvis ikke riktighet, men er ikke temaet videre her.

10. Olaussen finner tilsvarende formuleringer fra 1987 (Christie 1987), men det spørs om ikke disse tankene også kan leses inn i «Hvor tett et samfunn?» opprinnelig fra 1975 (Christie 1982a).

11. Avsnittet avsluttes slik: «Maktforskjeller gjør det også mindre ødeleggende for den sosiale fred å anvende straff mot utøvere av uønskede handlinger».

12. Olaussen har uttrykt seg kritisk til Høigårds fremstilling av definisjonsprosessen, og hevder at hun ikke belegger påstanden om at pressen skulle være premissleverandør for en fullstendig endring i folks oppfatninger om graffiti og tagging/maling (Olaussen 2008).

13. Christies posisjon inneholder altså også elementer av symbolsk interaksjonisme. Symbolsk interaksjonisme har et uavklart forhold til de store spørsmålene i sosiologien, men dette er ikke anledningen for å ta opp slike temaer.

14. Dette kan naturligvis også utnyttes politisk, og det er mulig det også skjer i en ikke ubetydelig utstrekning. 


\section{Litteratur}

Becker, H.S. (1973). Outsiders studies in the sociology of deviance. New York, Free Press.

Berger, P.L. and T. Luckmann (1992). Den samfundsskabte virkelighed: en videnssociologisk afhandling. København, Lindhardt og Ringhof.

Christie, N. (1982a). Hvor tett et samfunn? Oslo, Universitetsforlaget.

Christie, N. (1982b). Pinens begrensning. Oslo, Universitetsforlaget.

Christie, N. (1997a). «Straffens geografi». Nordisk tidsskrift for kriminalvidenskab(2): 89-102.

Christie, N. (2000). Kriminalitetskontroll som industri: mot GULAG, vestlig type. Oslo, Universitetsforlaget.

Christie, N. (2004). En passende mengde kriminalitet. Oslo, Universitetsforlaget.

Christie, N. and K. Bruun (1996). Den gode fiende narkotikapolitikk i Norden. Oslo, Universitetsforlaget.

Cohen, S. (1980). Folk devils and moral panics the creation of the Mods and Rockers. New York, St. Martin's Press.

Douglas, M. (1997). Rent og urent: en analyse av forestillinger omkring urenhet og tabu. Oslo, Pax.

Durkheim, É. (1982). The rules of sociological method and selected texts on sociology and its method. London, Macmillan.

Egge, M., J. Ganapathy, et al. (2008). Hvitt eller bredt?: rekruttering av minoritetsstudenter til Politihøgskolen. Oslo, Politihøgskolen.

Egge, M., M. Berg, et al. (2010). En god dag på jobben: evaluering av prosjektet «Trygghet og tillit». Oslo, Politihøgskolen.

Eia, H. og O.-M. Ihle (2010). Født sånn eller blitt sånn?: utro kvinner, sjalu menn og hvorfor oppdragelse ikke virker. Oslo, Gyldendal.

Ekanger, K. (1981). Politiets rolle i samfunnet: delutredning I. Oslo, Departementenes servicesenter, Informasjonsforvaltning.

Eriksen, S.S. og T. Kvilhaug (2002). «Redaksjonelt». Agora 20(1-2): 4.

Fekjær, S. (2014). Police students' social background, attitudes and career plans. Policing: International Journal of Police Strategies and Management 37 (2).

Finstad, L. (2000). Politiblikket. Oslo, Pax.

Finstad, L. (2009). Et Ansvarlig politi: åpenhet, kontroll og leering: evalueringsrapport fra utvalget oppnevnt av Justis- og politidepartementet 5. mars 2008. Oslo, Justis- og politidepartementet.

Foucault, M. (1999). Overvåkning og straff: det moderne fengsels historie. Oslo, Gyldendal.

Friestad, C. og I.L.S. Hansen (2004). Sammensatte levekårsproblemer blant innsatte $i$ norske fengsler. Oslo, Statistisk sentralbyrå. 18 (2004)nr 5.

Gergen, K.J. (2001). Social construction in context. London, Sage Publications.

Granér, R. (2004). Patrullerande polisers yrkeskultur. Lund, Socialhögskolan, Lunds universitet.

Grøvdal, Y. (2010). Kriminalitet - en sosial konstruksjon. Politivitenskap på egne ben? H.I. Gundhus, K. Hellesø-Knutsen and C.T. Wathne (red). Oslo, Politihøgskolen.

Hacking, I. (2000). Social konstruktion av vad? Stockholm, Thales.

Halvorsen, V. (2005). Politi, makt og demokrati. Politirollen gjennom 100 år: tradisjon og endring. M. Egge og J. Strype (red). Oslo, Politihøgskolen: s. 40-54. 
Halvorsen, V. (In press). «Crime does not exist»: remarks on Nils Christie’s A Suitable Amount of Crime (2004). Contemporary Perspectives on Foundational Texts in Criminology. M. Dubber. Oxford University Press.

Hammerlin, Y., C. Mathiassen, et al. (2006). Velferdsstatens velsignelser og farer: kriminalitet og samfunn 1965-2005. Oslo, KRUS.

Hauge, R. (1996). Straffens begrunnelser. Oslo, Universitetsforlaget.

Holmberg, L. (1999). Inden for lovens rammer: politiets arbeidsmetoder og konkrete skøn. København, Gyldendal.

Høigård, C. (2002). Gategallerier. Oslo, Pax.

Høigård, C. (2003). Kriminalitet: naturalisering av sosiale relasjoner. Fortsatt uferdig. K. Andenæs og K. papendorf (red). Oslo, Unipax: s. 188-199.

Johansen, N.B. (2008). Sosial kontroll i byer: to tradisjoner etter Durkheim og Tönnies. Oslo, Universitetet i Oslo.

Johansen, N.B. (2010). The problem with green criminology. NSfKs 52. forskerseminar. Økologisk og global kriminologi, Klekken, Norway, Nordisk Samarbejdsråd for Kriminologi.

Johansen, N.B. (2010b). «To tradisjoner i tenkingen om sosial kontroll». Sosiologisk Arbok(1): 22.

Politirolleutvalget (2005). Politiets rolle og oppgaver. Oslo, Justis- og, politidepartementet.

Larsson, P. (2010). Ideology as a cover up: community policing in Norway. Policing in Europe. A. Verhage (red). Journal of police studies 2010: 3/16.

Larsson, P. (2010a). «Fra armesterke bondesønner til akademikerbarn - Om rekrutteringen til politiyrket.» Nordisk Tidsskrift for Kriminalvidenskab.

Lie, G.E.M. (1999). Politivakten til hjelp og frustrasjon - hvordan opplever politiet denne type polititjeneste? Institutt for Kriminologi, Universitetet i Oslo.

Lundgaard, J.M. (2011). Nulltoleranse på norsk. Oslo, Unipub.

Mathiesen, T. (2011). Retten i samfunnet: en innføring i rettssosiologi. Oslo, Pax.

Neumann, I.B. (2011). Kriminalitet finnes. Morgenbladet. 16.09.2011.

Olaussen, L.P. (1981). Om kriminalstatistikken: datagrunnlag, opptellingsprinsipper og brukerproblemer. Oslo, Universitetsforlaget.

Olaussen, L.P. (1992). Introduksjon til kriminalstatistikken. Oslo, Universitetet i Oslo, Institutt for kriminologi.

Olaussen, L.P. (1995). «Voldskriminalitetens utvikling de to siste tiårene». Nordisk Tidsskrift for Kriminalvidenskab 82(2): 20.

Olaussen, L.P. (1996a). Kriminalstatistikk og virkelighet. Oslo, Politihøgskolen.

Olaussen, L.P. (1996b). Kriminalstatistikk som målestokk for kriminalitetsutviklingen. Institutt for kriminologi, Universitetet i Oslo.

Olaussen, L.P. (2004a). «Fruktbarhet sikres ved argumentasjon, ikke med erklæringer». Nordisk Tidsskrift for Kriminalvidenskab(5): 5.

Olaussen, L.P. (2004b). «Hvorfor er kriminalitet en sosial realitet?» Nordisk Tidsskrift for Kriminalvidenskab(1): 15 .

Olaussen, L.P. (2007a). «Kontrolltyper, kriminalitet og samfunn. Kritikk av Nils Christies kontrollteori om kriminalitet» Tidsskrift for samfunnsforskning(1): 35.

Olaussen, L.P. (2007b). «Sluttreplikk til Nils Christie». Tidsskrift for samfunnsforskning 48: 5. 
Olaussen, L.P. (2008). «Kriminalisering av graffiti - moral versus disiplinering som forklaring». Materialisten 36(1): 13.

Runhovde, S. (red.) (2010). Tillit til politiet. Oslo, Politihøgskolen.

Rønneberg, K.G. (2008). Politisamtaler med publikum: språkbruk som hemmer eller fremmer god kommunikasjon. [Oslo], Det humanistiske fakultet, Universitetet i Oslo.

Searle, J.R. (1969). Speech acts: an essay in the philosophy of language. Cambridge, Cambridge University Press.

Searle, J.R. (1995). The construction of social reality. London, Allen Lane.

Skarðhamar, T. (2002). Levekår og livssituasjon blant innsatte i norske fengsler. Oslo, Institutt for kriminlogi og rettssosiologi, Skriftserien.

Skog, O-J. (2006). Skam og Skade. Oslo, Gyldendal Akademisk.

Spector, M. og J. Kitsuse (1977). Constructing social problems. Menlo Park, California, Cummings.

Thomas, W.I. og D.S. Thomas (1928). The child in America behavior problems and programs. New York, Knopf.

Toje, A. (2012). Rødt, hvitt \& blått: om demokratiet i Europa. Oslo, Dreyers forlag. 